\title{
Psychological and Ethnocultural Sensitivities in the Perception of COVID-19 Memes by Young People in Russia and China
}

\author{
Olga V. Smirnova ${ }^{a^{*}}$, Galina V. Denissova ${ }^{\mathrm{b}}$, Luisa G. Svitich ${ }^{\mathrm{a}}$, Chuanzhao \\ Lin $^{a}$, Sofia B. Steblovskaia ${ }^{a}$, Alina S. Antipova ${ }^{b}$ \\ ${ }^{a}$ Faculty of Journalism, Lomonosov Moscow State University, Moscow, Russia \\ ${ }^{b}$ Faculty of Psychology, , Lomonosov Moscow State University, Moscow, Russia
}

${ }^{\star}$ Corresponding author. E-mail: smirnovaorama@gmail.com

Background. The COVID-19 pandemic has brought dramatic changes to all spheres of life. These changes have triggered an immediate response from the media, including social media, which repeatedly posts not only up-to-date information about this most relevant issue, but also users' reactions to it, including Internet memes.

Objective. The research presented in this article focused on comparing the psychological and ethnocultural sensitivities in the perception of COVID-19 memes by young people in Russia and China.

Design. The selected sample contained 108 respondents $(n=108)$, comprised of 50 Chinese and 58 Russian university students. The study consisted of two procedures: a survey and a student's t-test on the perception of specific Internet memes.

Results. The main results were that memes which evoke a positive response from the respondents and cheer them up were scored the highest. Such qualities as relevance, kindness, cheerfulness, creativity, meaningfulness, and thought-provoking ability were rated high. Each group of respondents gave a higher score to "our own" memes and a lower score to the other group's memes. It is generally typical of the Chinese to have a more positive perception of reality. We ascertained a tendency towards polarization of opinions and focus on individualization among the Russian respondents, whereas the Chinese respondents strove for orderliness and consensus.

Conclusion. As a whole, COVID-19 memes in such ethnoculturally different audiences as the Russians and Chinese serve a compensatory function for young people, helping them overcome the hardships of the pandemic through the memes' relevance and creative character.

\author{
Keywords: \\ COVID-19 \\ pandemic; \\ media; Internet; \\ memes; \\ perception; \\ young audience
}




\section{Introduction}

The COVID-19 pandemic has brought dramatic changes to all spheres of life. These changes have triggered an immediate response from the media, including social media, which repeatedly posts not only up-to-date information about this most relevant issue, but also users' reactions to it, including Internet memes (Pestova \& Safonov, 2020). "How the epidemic messages affect the public sentiment is an important issue with both theoretical and practical value" (Fang \& Haochen, 2020, p. 40).

A certain combination of text, cultural cliches, perceptions, and standard symbols capturing a kind of content, exists in the minds of people who share the same language and history. Together they form the cultural memory of common language speakers, what could be called "invariant images of the world" (Leontiev, 1997), without which no communication system could exist. The immense impact of the media in the current spread of the new coronavirus epidemic situation is evident: "...the news media should bear the responsibility of connecting society, fulfilling the basic responsibilities of the media, serving the people, and helping to scientifically regulate anti-epidemic measures" (Baowei \& Xinning, 2020, p. 10).

The conditions in which the media discourse takes shape are related, first, to the globalization of information exchange, which has overcome borders between countries, peoples, and ethnicities, and at the same time, led to more complex relationships and people's growing desire for self-identification and assertion of their status in a globalized world, including through information technology. Also, we cannot ignore the fact that the information system is changing dramatically, acquiring completely new characteristics, such as polysemanticity, duality, polycoding, simultaneity, virtualization, transboundariness, discreteness, etc. These specific features are combined with the ability of information to spread quickly, much like virus systems, in non-equilibrium transient states; reach a large audience (publicity factor); and thus become an independent economic, social, and psychological resource that affects the processes of material and spiritual exchange.

As a negative trend, it may be noted that present-day research into media discourse is becoming culturally monological, rather than dialogical and diversified (Shi-xu, 2009; Shi-xu, 2016). There is a growing, urgent need to employ crosscultural and interdisciplinary methods in discursive research, which would allow the most effective demonstration of the unique cultural heritage and intellectual achievements reflected in local media discourses.

It is important to note that the rapid spread of memes in recent years, and their noticeable impact on their audiences (especially young audiences), are attributed to their viral nature and their ability to embed themselves in human consciousness, serving the function of providing cultural patterns in communication (An, Cong, $\&$ Wang, 2004). In this respect, memes are a very important target for psychological, ethno-psycholinguistic, and sociological research.

In this paper, we consider the Internet meme to be a specific type of online message that brings together brief statements, different in their genres and semiotic nature, on topical issues which, due to their semantic scope and visual images, have a "viral nature;" meet the criterion of perceptual markedness (that is, they possess the intensity of information influence); and require appropriate perception by the addressee (Castaño, 2013; Wiggins \& Bowers, 2015; Shomova, 2018; Denissova, 
2020). We have selected "creolized memes" (Sorokin \& Tarasov, 1990; Kartashova \& Akhmedzianova, 2019) for our analysis, because this particular type of meme exerts influence through correlation between the visual imagery and the recipient's experience of it as a national culture bearer.

\section{Background}

Back in 1998, Bekhterev (1999) introduced the concept of "mental microbes,", which did not become very popular until mass media became widespread. The globalization of information has revolutionized communication, and led to formal written speech gravitating toward oral communication, on the one hand, and its "meme-ization" (Krongauz et al., 2017), on the other.

The term meme was introduced into scholarly discourse in 1976 by British evolutionary biologist Richard Dawkins $(1976 ; 1997)$, who used it to describe a unit of cultural information spread by imitation and replication. Later, researchers offered other interpretations of this concept, including one that defines the meme as a synonym for cultural replication on a representative basis, comparable to symbols and associations (Sperber, 1996). Another interpretation suggested that memes are ideas or representations, "the internal end of the knowledge relationship" (Plotkin, 1993). The emphasis was on the variability of memes as their key feature, as well as on their destructive effect on human consciousness, and their ability to influence people's actions (Dennett, 1995).

The phenomenon of Internet users turning into "memeboids," i.e., people who copy and replicate someone else's texts instead of generating their own, and thus pass on someone else's information, has been extensively studied (Ksenofontova, 2009). There has also been a focus on memes as cultural viruses, the memetics of religion, cult creation, and even the disinfection of society; the main means of meme distribution are being researched, such as repetition; cognitive dissonance, for the resolution of which new memes are introduced; genetic response, etc. (Brodie, 1996; Lynch, 1996).

Initially, the term meme was not related to computer technology; however, Douglas Rushkoff (1994), who studied the effect of pop culture on the mind, understood memes as containing hidden agendas and an ideological code that can infiltrate our mediasphere through the spread of seemingly innocuous cultural messages. He also introduced the term media virus and, building on Dawkins' work, described how media viruses are conceptually linked to biological ones, although media viruses spread through the datasphere instead of the body or community. "Instead of traveling along an organic circulatory system, a media virus travels through the networks of the mediaspace," he wrote. In addition, Rushkoff emphasized that "Once attached, the virus injects its more hidden agendas into the datastream in the form of ideological code - not genes, but a conceptual equivalent we now call 'memes"' (Rushkoff, 1994, p. 9-10).

The term meme was first used to mean a piece of culture, typically a joke, which gains influence through online transmission and functions online (Davison, 2012). Later on, the idea of techno-memes that are spread with people's participation but without any rational purpose on their part also appeared (Blackmore, 2010). So, the meme appears to be an essential part of Internet communication, and the interpretation and understanding of the meme continue to be the focus of research. Some 
researchers, for example Mikhail Epshtejn (2006), interpret the spread of "memes" as one of the main functions of a language (Chaoqun, 2007; Yunhui, 2010; Meiying, 2010); hence the importance of studying the psychological and ethnocultural factors influencing the choice of memes and their replication.

However, our study also had the objective of understanding the functioning of memes as a way to address the problem of maintaining health through the use of modern media. In general, recent trends show that the media are getting more and more interested in health topics; the events related to the 2020 COVID-19 pandemic have had a clearly dramatic impact on these trends, changing the approaches to this topic. Researchers have already started to assess these processes in terms of mediatization. Media research experts also emphasize that the most important factor that brought the issue of healthy living to the media forefront, is the dramatic change in the structure of the information and communications technology space which has taken place over the last few years (Vartanova, 2019).

Researchers in the field of psychology note that such a global challenge as the COVID-19 pandemic has increased health risks: some affected individuals have been reported to exhibit mental health problems, including stress, anxiety, depressive symptoms, fear, denial, and anger (Kang et al., 2020). Indeed, the level of stress that people all over the world have experienced, and are still experiencing in these new circumstances, is difficult to compare with any public health challenges that have ever existed. In its turn, this crisis cannot but lead to serious consequences, such as impairing individuals' immune systems (Tao, 2006), negatively impacting daily life, and reducing wellbeing (Holbrook et al., 2005), among others. In particular, researchers find it important to analyze the mental state of people from different age groups under such conditions, including students (Jieling et al., 2014), and the potential aggravation of students' psychological distress during the COVID-19 outbreak (Xiao \& Benxian, 2020).

To understand the role of the media as a tool that individuals can use to cope with the stresses caused by events such as the pandemic, earlier research on different aspects of the problem has been useful (Green \& Rodgers, 2001; Martire, Stephens, \& Townsend, 1998; Gadalla, 2009; Assari, 2019; Bennetter, Clench-Aas, \& Raanaas, 2016; Keeton et al., 2008).

Social support would be associated with reduced acute stress symptoms, which are viewed by researchers as a common mental health problem in the period following the COVID-19 outbreak (Xiao \& Benxian, 2020).

In this context, we believe that the study of the impact of different types of media content on people's psychological state is extremely relevant. There is almost no cross-cultural research on this issue yet. Therefore, it is very important to understand the ethnocultural sensitivities in the perception of this media content by recipients from countries with radically different cultural experiences, such as Russia and China. This is the subject our study addressed.

The purpose of our study was the research of to explore the psychological and ethnocultural sensitivities in the perception of Internet memes related to the COVID-19 pandemic by young people in Russia and China. The subject of the memes was chosen because the pandemic issue is now at the top of people's agendas; moreover, the choice of Internet memes with a single subject will allow us to identify differences in their perception by different audiences more effectively. 
The main issues of the questionnaire (Zinchenko, Shaigerova, \& Soldatova, 2016; Zizevskaia \& Shchukina, 2018) we used touched on various ethnic and socially significant aspects of human behavior related to the impact of memes on people's psychological condition during self-isolation. The questionnaire addressed various ethnic and socially significant aspects of human behavior. We chose a young audience as the target of our research because of the importance of media consumption by present-day youth. Researchers emphasize that the Internet is an extremely important and habitual source of information for young people (Vartanova, Cherevko, Tolokonnikova, \& Dunas, 2019). They also stress the need for studying such important processes as socialization and self-actualization in the media practices of youth involved in digital media culture (Dunas \& Vartanov, 2020).

From an ethno-psycholinguistic perspective, it appears that the Internet meme is not well understood as performing the function of expressing a cultural pattern in communication and being integral to the manifestation of an ethnocultural identity. In this regard, studies focused on the aspects of mutual understanding when interpreting the same phenomena by speakers from different languages/cultures become increasingly important, since memes from different nations may differ in their degree of structural complexity and accuracy of reflecting reality. Therefore, it is important to:

1. Identify the psychological and ethnocultural sensitivities in the perception of "native" Internet memes, and carry out a comparative analysis of the perception of Chinese memes by Russian respondents and Russian memes by Chinese respondents; and

2. Identify the psychological and ethnocultural sensitivities in the perception of "non-native" Internet memes, and carry out a comparative analysis of the perception of Chinese memes by native Russian speakers and Russian memes by native Chinese speakers.

Research hypothesis: Although a meme is the result of frame processing and complex thinking by the human mind (and in this sense, it has a lot in common with percepts, gestalts, symbols, etc.), and its perception is determined by the recipient's ethnocultural identity, COVID-19 memes also equally serve a compensatory function for both Russian and Chinese youth audiences, helping them overcome, through their relevant content and creative form, the hardships of the pandemic and the negative effects of self-isolation, restricted freedom of action, and the lack of face-to-face communication.

\section{Methods}

\section{Participants}

Our sample contained 108 respondents $(\mathrm{n}=108)$, including 50 Chinese and 58 Russian university students (both Humanities and Engineering), enrolled in different degree programs: bachelor's ( $42 \%)$, master's $(32 \%)$, and postgraduate (26\%). It included $36 \%$ men and 64\% women. Respondents' age groups were: 18 to 22 years old (39\%); 23 to 27 years old (46\%); and 28 to 32 years old (15\%). 
Our study began on April 1, 2020, during the COVID-19 outbreak. We focused on university students, because all the universities in both countries were closed in order to reduce the likelihood of teachers and students becoming infected with the virus. Students were studying from home during this period. During the survey (April-June 2020), all the respondents were in self-isolation. All 58 Russian respondents were students of various universities in Moscow, but at the time of the survey, they were both in Moscow and in 18 other Russian regions (one student even had an internship at a university in Belgium). Out of the 50 Chinese respondents, 14 people were outside China (most of them were in Russia, and one student was in the U.S.), and 36 people were in 25 cities of China, spread over 16 provinces.

All schools and universities in both China and Russia were closed until September 2020, and students took online classes. The movements of students on campus were severely restricted. China introduced unprecedented and very strict measures to contain the virus. As part of these measures, starting in February, each and every student in China had to report his/her location and health status on a daily basis, using a special mini application in WeChat. The borders of both China and Russia were closed starting March 28, 2020, and are still closed.

We conducted an Internet-based survey to assess psychological responses among students. Using the emailing platform, we sent a questionnaire to some students and invited them to respond and invite their friends who were also students to respond. Using this method, we recruited 108 participants in several regions in Russia and provinces in China.

\section{Procedure}

The study consisted of two procedures. The first one was a survey among respondents about their attitudes towards Internet memes related to the COVID-19 pandemic. The questionnaire included basic questions about the social media used by the respondents and their functions (entertainment, distraction, emotional experience, communication, identification, information, compensatory and contact functions); respondents' preferences for different types and topics of memes; and the perception and influence of memes on the respondents. The topics and wording of the questions aimed to identify the role of memes and their impact on the respondents' psychological condition during the coronavirus pandemic and selfisolation.

The second procedure involved a test on the perception of specific Internet memes by the respondents. We selected a sample from popular memes oin the Russian and Chinese Internet sectors. The memes were selected as follows: for one month (15 April 15 - 15 May 15, 2020), 10 student volunteers students from Moscow State University (5 Russian nationals and 5 Chinese nationals) monitored their social media to find pandemic-related memes. The main criteria for selecting the memes were their relevance and a high level of popularity among the audience (a significant number of likes). As a result of such the monitoring, we have removed duplicating memes and compiled an array $(\mathrm{N}=400)$, including $\mathrm{N}=200$ Russian memes and $\mathrm{N}=200$ Chinese memes. After that, we selected the creolized memes, - that is, those with an image (photos, drawings, paintings or mixed forms) and a text - , since the creolized meme is a kind of universal code capable of recoding into the areas of both language and thought $(\mathrm{N}=267)$. Preference was given to clear, 
easy-to-understand images with large and concise text, accessible to both the Russian and Chinese audiences.

In addition, the selected memes showed different objects such as people, animals, nature, symbols, etc. in different forms, including realistic and fantasy images, photos, drawings, paintings, and creative and standard images. In the final stage of selection, we took into account the presence of the memes in the feeds of the students who had compiled the basic array. Using these criteria, a total of 10 memes (5 Russian and 5 Chinese) were selected; each of them was given a sequential number and a conventional name.

A special procedure was developed for the perception test that was used each of the 10 memes with 11 opposite binary characteristics: interesting - boring; current - outdated; useful - useless; clear - incomprehensible; creative - unoriginal, etc. The respondents marked a score of 3 to 1 , or 1 to 3 , depending on their positive or negative attitude ( 3 was a high degree; 2 was a medium degree; 1 was a low degree; and 0 was a neutral attitude), in the cells between each characteristic. In addition, the respondents were to suggest a name for each meme, describe the mood and associations brought up by the memes, and rate them on a 5-point scale. In addition, each respondent was to give a brief verbal description to each meme.

In order to test the hypothesis that there are differences between the Russian and Chinese samples in their perception of memes associated with COVID-19 pandemic, the Student's t-test for independent samples was used.

\section{Results}

The table below shows the answers to the question of why COVID-19 memes had attracted the respondents' attention (see Table 1).

Table 1

Why do COVID-19 memes attract your attention? (\% of the number of respondents)

\begin{tabular}{lccc}
\hline \multicolumn{1}{c}{ Answer options } & $\begin{array}{c}\text { Russians } \\
\mathbf{n = 5 8}\end{array}$ & $\begin{array}{c}\text { Chinese } \\
\mathbf{n = 5 0}\end{array}$ & $\begin{array}{c}\text { Average } \\
\mathbf{n = 1 0 8}\end{array}$ \\
\hline This is the most relevant issue & 43 & 72 & 58 \\
It attracts me because of its humor & 31 & 46 & 37 \\
It's interesting and made with a flight of imagination & 17 & 54 & 34 \\
It helps me to deal with self-isolation and compensates & 28 & 38 & 32 \\
for anxiety & & 24 & 23 \\
It cheers me up & 16 & 30 & 22 \\
It helps me to relax and have a break & 12 & 32 & 21 \\
I want to know what people think about it & 3 & 18 & 10 \\
I collect Internet memes & 9 & 10 & 9 \\
I find people who feel the same way I do, by seeing how & & & 7 \\
they react to memes & 14 & 0 & \\
It helps me to connect with and talk to other people on & & & \\
the Internet & & & \\
\hline
\end{tabular}


The following table shows the breakdown of answers to the question that allowed us to identify the semantic aspects of meme perception (see Table 2).

Table 2

What are the topics of COVID-19 memes you are most interested in? (\% of the number of respondents)

\begin{tabular}{lccc}
\hline \multicolumn{1}{c}{ Answer options } & Russians & Chinese & Average \\
\hline Working from home and self-isolation & 71 & 56 & 64 \\
Government officials and the pandemic & 40 & 30 & 35 \\
Wear a mask and gloves & 24 & 38 & 31 \\
Combating the virus & 28 & 44 & 27 \\
Prevention & 5 & 48 & 25 \\
Borders closed & 16 & 26 & 20 \\
Virus origin & 5 & 36 & 19 \\
Doctors as heroes & 7 & 17 & 19 \\
Supply shortage & 19 & 14 & 17 \\
\hline
\end{tabular}

The questionnaire also contained an open question on what attracted the students to memes related to the COVID-19 pandemic. Here, the pivotal motives were relevance, creativity, and humor to help people to get through the pandemic. Below are a few quotes that will help the reader better understand the reasons why the respondents chose this form of content:

"I like it when people are capable of analyzing what is happening in the world and joking about it."

"Memes allow us to maintain contact with the outside world and keep track of all global developments."

"Relevance, cheerfulness, and humor distract from the constant thought: "When will it end?"

"It allows us to survive self-isolation more easily and not to despair."

"It helps to wrap your mind around this and take it easier."

"Memes are an alternative source of news, a digest of the most important things."

"Memes ease tension and raise spirits."

"For me, it's an escape; I can let off steam".

"It would be very sad to talk about this touchy issue without humor."

"Memes help you level out the negative effect and smile at the situation."

Finally, the most important and interesting part was the results of the test where respondents rated the 10 memes they were offered for evaluation (see Table 3 and Table 4). 


\section{Table 3}

Answers to the question: Rate the meme on a five-point scale (Russian memes)

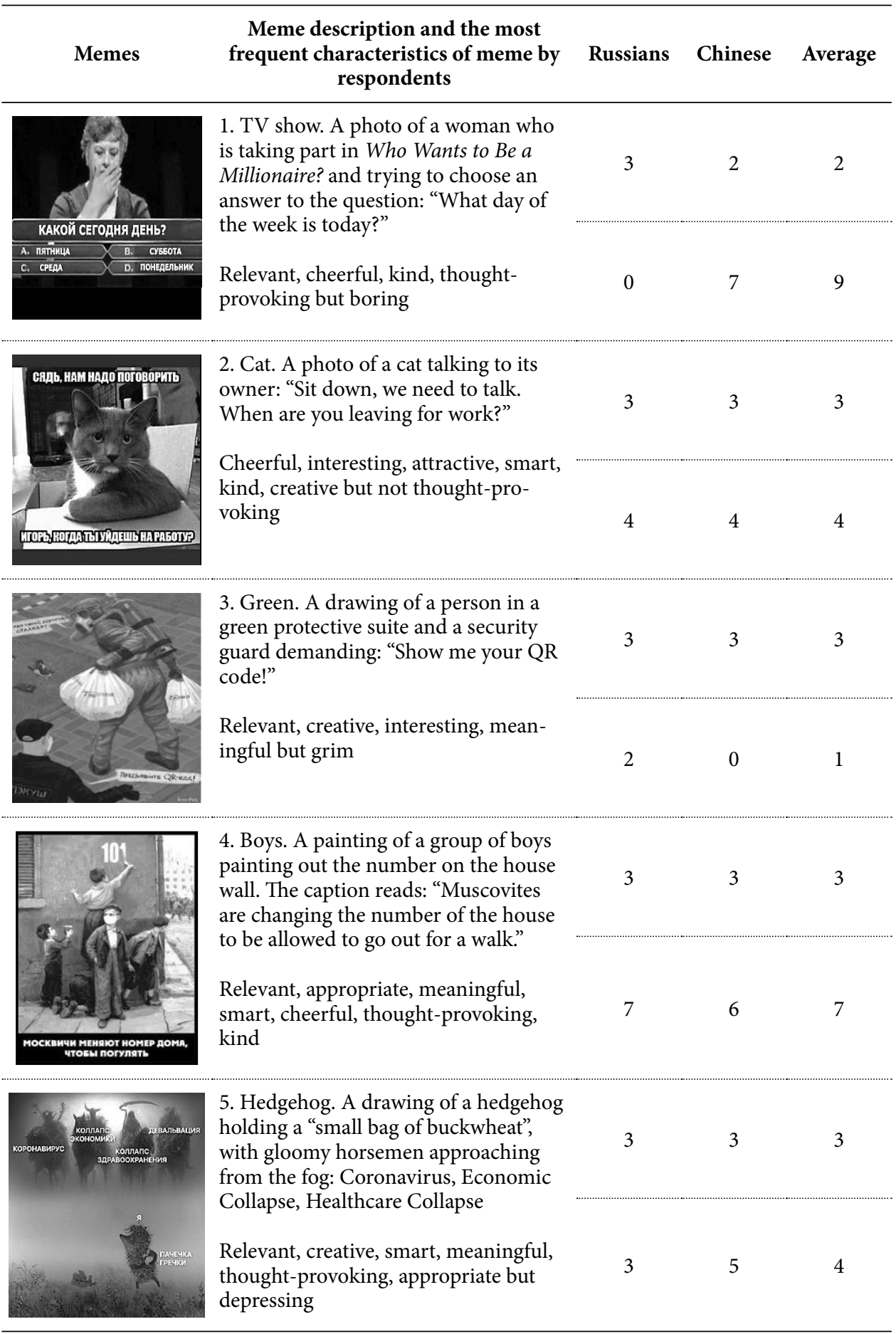


Table 4

Answers to the question: Rate the meme on a five-point scale (Chinese memes)

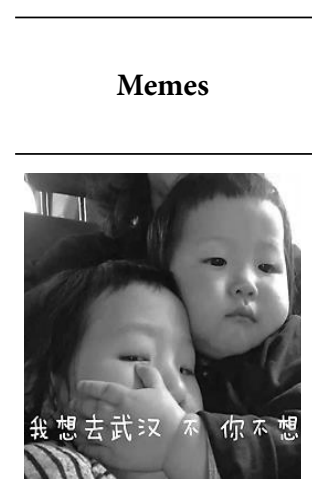

\section{Meme description and the most frequent characteristics of meme by respondents}

\section{Russian Chinese Average}

6. Girls. A photo showing two little girls. The caption reads: "I want to go to Wuhan!" - "No, you don't!" 2

Neutral attitude. Some of the accents: relevant and kind, but straightforward, outdated, not thought-provoking, annoying

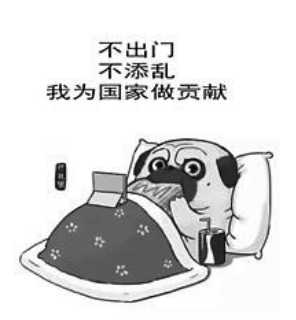

7. Doggy. A drawing of a doggy (in anime style) in bed. The caption reads: "I am staying at home! I am not panicking! This is what I do for my country!”

Relevant, kind, appropriate, attractive, cheerful but straightforward

3

3

3

$3-3$

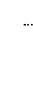

$2 \quad 3$

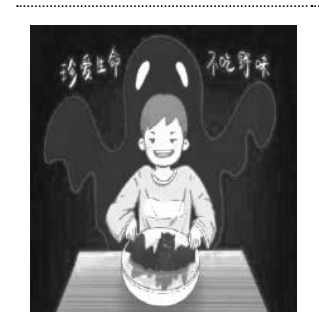

8. Lunch. A drawing of a boy, with a huge bowl with a bat in front. The caption reads: "Take care! Don't eat it!"

2

Appropriate, thought-provoking but depressing, grim, straightforward, annoying

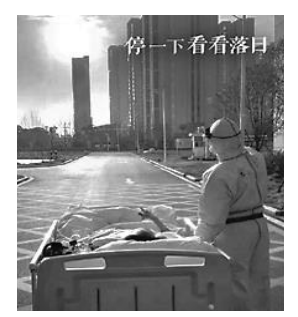

9. Sunset. A drawing of a doctor (in fantasy style) wheeling a bed with a patient in it. The caption reads: "Stop and watch the sunset!"

Makes less sense for the Russians than other memes but relevant although depressing

2

2

2

10. Piggy. A photo of a piggy hanging

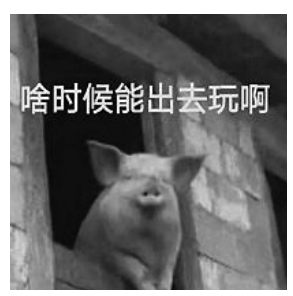
out of the window. The caption reads: "When will I be allowed to go out for a walk?"

Relevant, cheerful, interesting, attractive, kind 
In order to test the hypothesis that there are differences between the Russian and Chinese samples in the perception of memes associated with COVID-19 pandemic, the Student's t-test for independent samples was used.

First of all, we attempted to find out whether there were universal differences between the two groups, unspecific to the particular memes. On average, the Russians gave lower scores across all scales apart from clearness (see Figure 1), although only "clearness," "importance," and "thoughtfulness" showed significant differences after the Holm-Bonferroni correction (Sture, 1979) was applied to reduce the family-wise error rate. Comparative statistics and $p$-values are presented in Table 5.

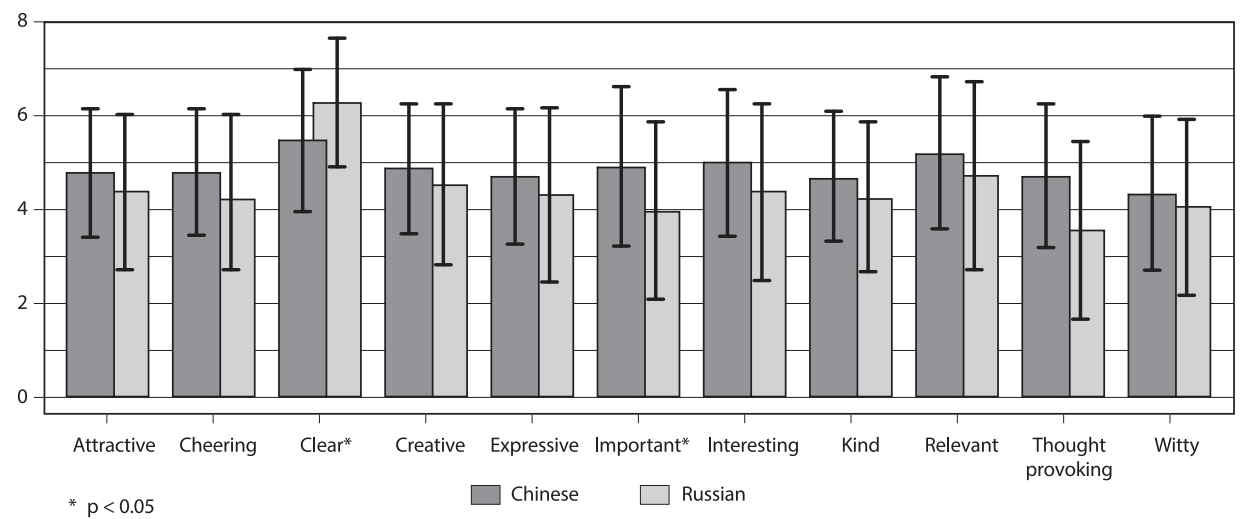

Figure 1. General meme assessment by nationality.

Table 5

Comparison statistics and p-values (Universal differences)

\begin{tabular}{lcccc}
\hline & $\mathbf{T}$ & $\mathbf{p}$-value & $\mathbf{D f}$ & Adj. $\mathbf{p}$-value $^{*}$ \\
\hline Attractive & 1.32 & 0.186 & 1077.3 & 0.186 \\
Cheering & 1.67 & 0.096 & 1070.5 & 0.096 \\
Clear & 2.69 & 0.007 & 1026 & $0.043^{*}$ \\
Creative & 1.16 & 0.246 & 1075.1 & 0.246 \\
Expressive & 1.21 & 0.227 & 1066.6 & 0.227 \\
Important & 2.7 & 0.007 & 1076.7 & $0.049^{\star}$ \\
Interesting & 1.87 & 0.062 & 1076.3 & 0.062 \\
Kind & 1.55 & 0.121 & 1077.5 & 0.121 \\
Relevant & 1.33 & 0.184 & 1072.8 & 0.184 \\
Thought & 3.39 & $<0.001$ & 1072.8 & $0.006^{* *}$ \\
provoking & 0.91 & 0.365 & 1077.8 & 0.365 \\
Witty & & & &
\end{tabular}

Note. ${ }^{*}$ using Holm-Bonferroni correction; ${ }^{*} p<0.05,{ }^{* *} p<0.01$ 
Table 6

Comparison statistics and p-values (Specific differences)

\begin{tabular}{|c|c|c|c|c|c|c|c|c|c|c|c|}
\hline & & $\begin{array}{c}\text { TV } \\
\text { show }\end{array}$ & at & n & ys & $\begin{array}{c}\text { Hedge } \\
\text { hog }\end{array}$ & ls & $\operatorname{og}$ & h & t & Piglets \\
\hline \multirow{2}{*}{ A } & & & 0.10 & . & 0.11 & 0.07 & 1.30 & 0.41 & .11 & 1.18 & 1.70 \\
\hline & & 277 & 920 & .456 & .684 & 0.521 & 0.197 & 0.680 & 0.271 & .241 & .155 \\
\hline \multirow{2}{*}{ eering } & & & & & & & & 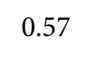 & .51 & $4.13^{\star * \star}$ & 1.09 \\
\hline & & 0.918 & 0.856 & 0.187 & 0.792 & 0.782 & 0.658 & 0.572 & 0.613 & $<0.001$ & 0.278 \\
\hline \multirow{2}{*}{ C } & & & & & & & & & & 0.06 & \\
\hline & & 001 & .058 & 0.015 & 0.116 & 0.078 & 0.785 & 0.160 & 0.884 & 0.949 & 0.914 \\
\hline \multirow{2}{*}{ Creative } & & . & 1.00 & 1.00 & 0.7 & 0.26 & $1 . / 1$ & .00 & 15 & 1.00 & 1.50 \\
\hline & & 0.064 & 0.186 & 0.096 & 0.665 & 0.796 & 0.091 & 0.975 & 0.879 & 0.281 & 0.124 \\
\hline \multirow{2}{*}{ Expre } & & & 132 & 10e & & & 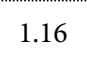 & 07 & 54 & 79 & 1.42 \\
\hline & & $t$ & 6 & 0.284 & 59 & 0.953 & 8 & 8 & 3 & 7 & 58 \\
\hline \multirow{2}{*}{ Important } & & & & & & & . & 1.58 & 0.70 & $2.40^{*}$ & 1 \\
\hline & & 0.264 & .168 & 0.420 & 0.662 & 0.175 & 0.023 & 0.118 & 0.483 & 0.018 & 0.110 \\
\hline \multirow{2}{*}{ Interesting } & & & & & 0.05 & & 2.19 & 0.12 & .10 & $2.84^{4}$ & $1 . / 6$ \\
\hline & & (200 & & 6 & 9 & 877 & 0.031 & .472 & 0.275 & 0.005 & 0.081 \\
\hline \multirow{2}{*}{$\mathrm{K}$} & $t_{1}$ & & & & & & & & $2.19^{*}$ & & \\
\hline & & 0.836 & 0.700 & 0.005 & 0.432 & 0.227 & 0.783 & 0.243 & 0.031 & 0.030 & 0.740 \\
\hline \multirow{2}{*}{ Relevant } & & 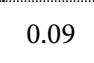 & 0.71 & 0.40 & 0 & 1.57 & 2.10 & .01 & 50 & 0 & 0.65 \\
\hline & & 0.930 & 0.482 & 0.649 & 0.980 & 0.120 & 0.034 & 0.312 & 0.578 & 0.766 & 0.519 \\
\hline \multirow{2}{*}{$\begin{array}{l}\text { Thought } \\
\text { provoking }\end{array}$} & & 1.63 & $2.04^{\star}$ & 0.43 & 1.53 & 1.66 & $2.24^{\star}$ & 1.12 & $2.14^{*}$ & $2.17^{*}$ & 1.73 \\
\hline & $\mathrm{p}-\mathrm{v}$ & 0.106 & 0.044 & 0.666 & 28 & 101 & 0.027 & 56 & 0.035 & 0.033 & 87 \\
\hline \multirow{2}{*}{ Witty } & ${ }^{1}(1$ & 0.10 & ( & 0.01 & 1.02 & 0.2 & 1.07 & 0.03 & 0.07 & 1.82 & 1.10 \\
\hline & $\mathrm{p}$-value & 0.435 & 0.709 & 0.993 & 0.311 & 0.775 & 0.182 & 0.530 & 0.943 & 0.072 & 0.274 \\
\hline
\end{tabular}

Note. ${ }^{*} p<0.05,{ }^{* *} p<0.01,{ }^{* * *} p<0.001$

After that, we investigated which memes contributed the most to the mentioned difference. "Boys," "Hedgehog," "Dog," "Lunch," and "Piglets" memes showed no significant differences between Russian and Chinese assessments at $\mathrm{p}$-value $\leq 0.05$, while the most divisive ones turned out to be "Sunset" and "Girls." For comparison statistics and p-values (see Table 6) and for descriptive statistics (see Table 7).

"TV-show" was rated as the clearest one, but less expressive by the Russian respondents compared to the Chinese ones (see Figure 2). The "Cat" meme was rated more thought-provoking by the Chinese respondents (see Figure 3). "Green" was deemed easier to understand by the Russians, but kinder by the Chinese (see Figure 4). "Girls" seemed more important, interesting, relevant, and thought- 


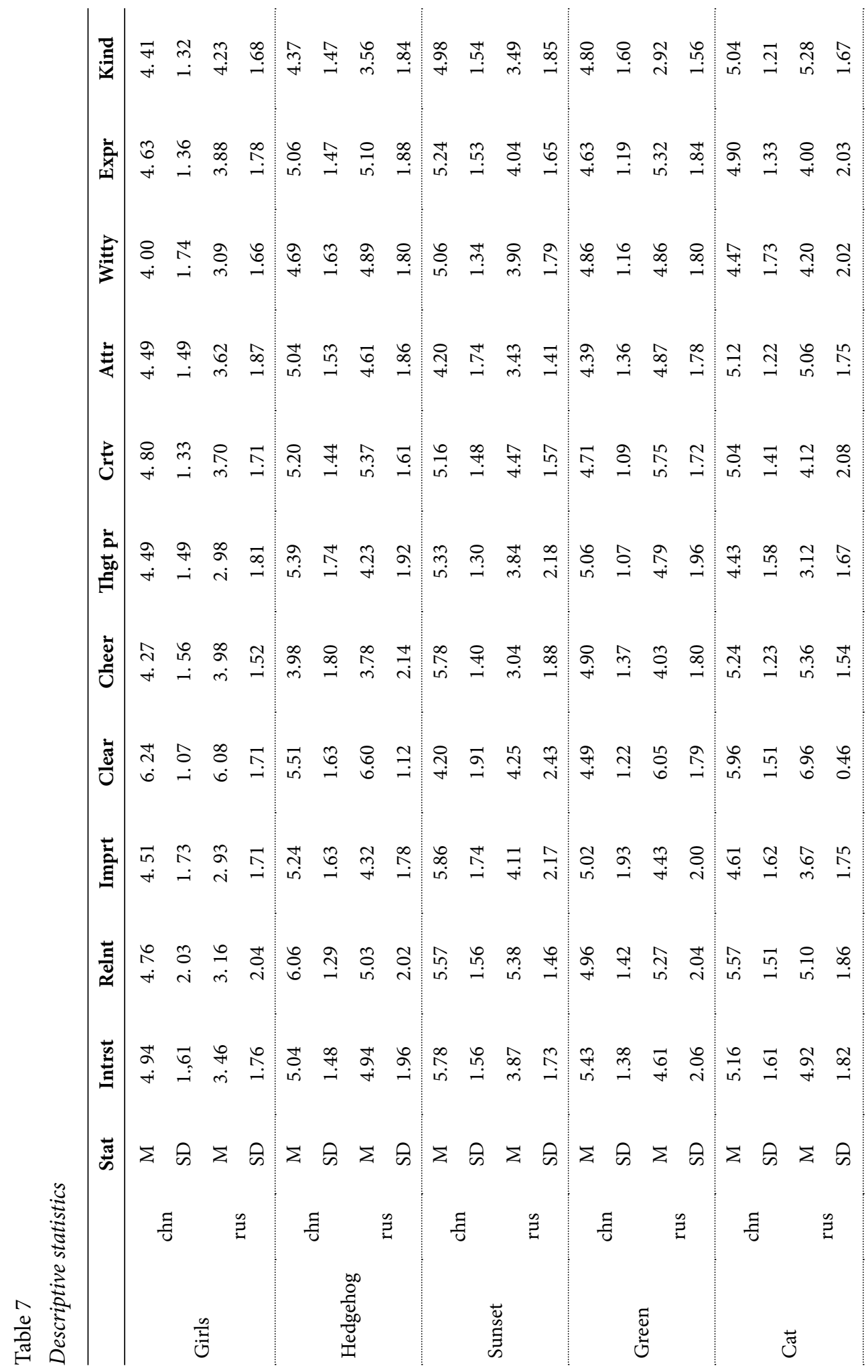




\begin{tabular}{|c|c|c|c|c|c|c|c|c|c|c|c|c|c|c|c|c|c|c|c|c|}
\hline$\vec{\Xi}$ & 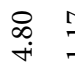 & $\stackrel{\beth}{\rightleftarrows}$ & $\begin{array}{l}\stackrel{\infty}{\sim} \\
\text { in }\end{array}$ & กָ & તิ & 尺. & $\begin{array}{l}\infty \\
i \\
i\end{array}$ & in & $\begin{array}{l}\stackrel{ }{\rightarrow} \\
\text { in }\end{array}$ & $\stackrel{\infty}{\rightleftarrows}$ & 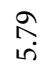 & ભે & ले & 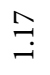 & $\stackrel{\infty}{\stackrel{\infty}{*}}$ & $\underset{-}{\overrightarrow{0}}$ & $\begin{array}{l}\vec{b} \\
\overrightarrow{+}\end{array}$ & $\stackrel{m}{=}$ & $\stackrel{\Re}{\stackrel{n}{f}}$ & $\stackrel{+}{\ddot{n}}$ \\
\hline 育 & $\stackrel{4}{\stackrel{4}{n}}$ & 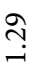 & $\begin{array}{l}\hat{\sigma} \\
\dot{\varphi}\end{array}$ & $\stackrel{\vec{b}}{-}$ & $\stackrel{\infty}{\stackrel{\infty}{m}}$ & . & $\stackrel{m}{\dddot{n}}$ & 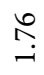 & ले & 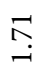 & $\stackrel{\vec{H}}{\text { mे }}$ & $\widetilde{\Omega}$ & $\underset{\text { in }}{\text { in }}$ & $\stackrel{\bullet}{\bullet}$ & $\stackrel{\wp}{\not}$ & $\stackrel{\hat{O}}{i}$ & f & $\stackrel{\overbrace{}}{-}$ & $\stackrel{n}{\circ}$ & $\stackrel{\hat{O}}{i}$ \\
\hline 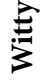 & ช̂ & $\stackrel{\Re}{\stackrel{n}{-}}$ & in & $\stackrel{a}{b}$ & $\vec{m}$ & $\alpha$ & $\stackrel{\check{n}}{m}$ & $\stackrel{\overbrace{}}{\circledR}$ & $\stackrel{\circ}{\underset{+}{+}}$ & $\stackrel{g}{b}$ & $\begin{array}{l}\stackrel{8}{\circ} \\
\dot{r}\end{array}$ & $\stackrel{+}{i}$ & $\begin{array}{l}\tilde{6} \\
+ \\
+\end{array}$ & $\stackrel{\infty}{-\infty}$ & $\begin{array}{l}m \\
\infty \\
m\end{array}$ & $\underset{i}{+}$ & $\stackrel{\text { กิ }}{+}$ & $\underset{ت}{\stackrel{F}{\longrightarrow}}$ & $\begin{array}{l}\infty \\
\stackrel{\infty}{\infty} \\
\dot{m}\end{array}$ & $\stackrel{\infty}{\infty}$ \\
\hline$\sum_{Z}^{ \pm}$ & $\stackrel{m}{m}$ & $\stackrel{\overbrace{}}{\rightleftarrows}$ & $\begin{array}{l}\infty \\
\infty \\
i \\
i\end{array}$ & ڤn? & $\stackrel{\text { ঙे }}{\text { I }}$ & $\stackrel{\infty}{\stackrel{\infty}{n}}$ & 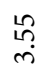 & $\underset{\text { ọ }}{\text {. }}$ & $\begin{array}{l}\circ \\
\text { in }\end{array}$ & $\stackrel{\sim}{\sim}$ & in & $\stackrel{\infty}{\stackrel{\infty}{+}}$ & $\begin{array}{l}\hat{b} \\
\text { in }\end{array}$ & $\stackrel{n}{\oplus}$ & 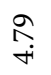 & $\vec{b}$ & $\stackrel{\substack{\infty \\
+}}{+}$ & $\stackrel{n}{a}$ & $\stackrel{\overrightarrow{+}}{+}$ & గి \\
\hline : & $\begin{array}{ll}10 \\
6 \\
\text { in }\end{array}$ & $\begin{array}{l}\infty \\
\stackrel{\infty}{\circ} \\
-\end{array}$ & 各 & 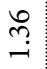 & $\underset{+}{F}$ & ت্ّ & $\vec{m}$ & $\stackrel{+}{\stackrel{1}{-}}$ & $\begin{array}{l}\hat{\sigma} \\
\dot{+}\end{array}$ & $\underset{\sim}{\widetilde{\sigma}}$ & $\begin{array}{l}\stackrel{2}{0} \\
+ \\
+\end{array}$ & ڤ̊ำ & $\begin{array}{l}\stackrel{n}{m} \\
\stackrel{n}{n}\end{array}$ & $\stackrel{\leftrightarrow}{\mathscr{n}}$ & $\stackrel{\text { సे }}{+}$ & $\stackrel{\sigma}{\sigma}$ & in & $\underset{ت}{ت}$ & $\stackrel{\sim}{m}$ & $\stackrel{8}{9}$ \\
\hline$\frac{\vec{b}}{\vec{b}}$ & $\stackrel{\infty}{\overrightarrow{1}}$ & 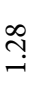 & $\begin{array}{l}\underset{7}{+} \\
+\end{array}$ & $\stackrel{\infty}{\stackrel{-}{-}}$ & $\begin{array}{l}b \\
\cdots \\
i n\end{array}$ & $\stackrel{શ}{\stackrel{2}{-}}$ & $\stackrel{8}{\ddot{r}}$ & $\stackrel{\leftrightarrow}{\Omega}$ & 華 & nิ & $\stackrel{\curvearrowright}{\hat{n}}$ & $\widehat{\widehat{S}}$ & $\stackrel{\underset{H}{H}}{+}$ & $\stackrel{+}{-}$ & 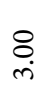 & $\stackrel{\infty}{\infty}$ & $\underset{+}{\stackrel{+}{+}}$ & $\stackrel{\vec{b}}{-}$ & $\stackrel{\text { \} }{\text { ஸे }}} &{\stackrel{9}{9}} \\
{\hline \frac{\vec{\Xi}}{\tilde{U}}} &{\stackrel{丶}{\stackrel{+}{+}}} &{\stackrel{m}{-}} &{\stackrel{m}{i n}} &{\stackrel{+}{\stackrel{+}{-}}} &{\text { 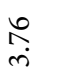 }} &{\stackrel{\vec{n}}{-}} &{\stackrel{\text { f }}{m}} &{\stackrel{શ}{\stackrel{\imath}{r}}} &{\underset{i n}{7}} &{\vec{m}} &{\text { 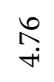 }} &{\stackrel{\Re}{i}} &{\overrightarrow{\widehat{N}}} &{\Xi} &{\begin{array}{l}\vec{b} \\
\dot{i n}\end{array}} &{\underline{\Sigma}} &{\begin{array}{l}\qquad \tilde{b} \\
\dot{+}\end{array}} &{\stackrel{t}{0}} &{\stackrel{\vec{r}}{+}} &{\text { in }} \\
{\hline \stackrel{\vec{\Xi}}{\vec{J}}} &{\vec{r}} &{\text { 号 }} &{\begin{array}{l}6 \\
6 \\
0\end{array}} &{\stackrel{0}{\simeq}} &{\vec{n}} &{\text { 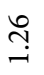 }} &{\text { ?̊? }} &{\stackrel{+2}{n}} &{\text { o }} &{\stackrel{\overbrace{}}{\text { I }}} &{\vec{\infty}} &{\stackrel{n}{\hat{0}}} &{\text { ñ }} &{\stackrel{\infty}{\sigma}} &{\text { ڤู }} &{\text { 욱 }} &{\begin{array}{l}\infty \\
\infty \\
+ \\
+\end{array}} &{\hat{\tilde{n}}} &{\stackrel{\infty}{\text { ఫొ }}} &{\stackrel{\pi}{t}} \\
{\hline \text { 竞 }} &{\underset{\text { in }}{7}} &{\stackrel{\text { ff }}{-}} &{\begin{array}{l}M \\
\infty \\
+ \\
+\end{array}} &{\stackrel{શ}{\stackrel{\imath}{-}}} &{\stackrel{\infty}{\stackrel{+}{+}}} &{\widehat{\widehat{a}}} &{\stackrel{\stackrel{9}{+}}{+}} &{\stackrel{\vec{\lambda}}{i}} &{\text { กี }} &{\stackrel{\Delta}{\sigma}} &{\stackrel{2}{\overrightarrow{+}}} &{\stackrel{\vec{i}}{\vec{i}}} &{\frac{\infty}{10}} &{\stackrel{\widetilde{\sigma}}{-}} &{\underset{+}{\stackrel{一}{+}}} &{\stackrel{\leftrightarrow}{\rightarrow}} &{\underset{+}{\stackrel{8}{+}}} &{\stackrel{n}{\stackrel{n}{\check{r}}}} &{\vec{m}} &{\stackrel{n}{\beta}} \\
{\hline \underset{\Xi}{\tilde{\Xi}}} &{\text { ๙ิ }} &{\text {. }} &{\begin{array}{l}8 \\
\text { in }\end{array}} &{\stackrel{8}{\stackrel{8}{-}}} &{\text { 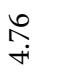 }} &{\underset{i}{\stackrel{2}{c}}} &{\stackrel{m}{\sim}} &{\stackrel{\infty}{\sim}} &{\stackrel{m}{m}} &{\stackrel{\bullet}{\bullet}} &{\underset{\mathscr{H}}{\tilde{+}}} &{\text { 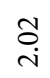 }} &{\text { in }} &{\stackrel{?}{\stackrel{1}{-}}} &{\vec{F}} &{\stackrel{\hat{O}}{i}} &{\stackrel{\hat{m}}{+}} &{\stackrel{\widehat{\sigma}}{-}} &{\stackrel{\mathscr{P}}{+}} &{\underset{i}{\vec{H}}} \\
{\hline \stackrel{\overrightarrow{0}}{\Xi}} &{\stackrel{n}{n}} &{\stackrel{m}{\rightleftarrows}} &{\text { हे }} &{\stackrel{\infty}{\stackrel{\infty}{-}}} &{\underset{+}{\stackrel{\sim}{*}}} &{\stackrel{\widehat{\sigma}}{-}} &{\begin{array}{l}\infty \\
\infty \\
+ \\
+\end{array}} &{\stackrel{\varkappa}{-}} &{\text { 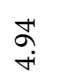 }} &{\text { 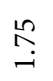 }} &{\underset{f}{\stackrel{m}{+}}} &{\stackrel{+\infty}{\infty}} &{\text { in }} &{\text { 도 }} &{\stackrel{\stackrel{n}{m}}{+}} &{\stackrel{\infty}{\stackrel{\leftrightarrow}{-}}} &{\stackrel{m}{m}} &{\stackrel{\mathfrak{a}}{-}} &{\stackrel{N}{\stackrel{N}{n}}} &{\stackrel{\infty}{\leftrightarrow}} \\
{\hline \text { సँ }} &{\Sigma g} &{\text { हे }} &{\Sigma} &{\text { a }} &{\Sigma} &{\text { a }} &{\Sigma} &{\text { के }} &{\Sigma} &{\text { a }} &{\Sigma} &{\text { क }} &{\Sigma} &{\text { के }} &{\Sigma} &{\text { s }} &{ } &{\text { क }} &{\Sigma} &{\text { के }} \\
{\hline} &{\text { శี }} &{ } &{\text { 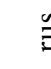 }} &{ } &{\text { द्वี }} &{ } &{ } &{\text { E }} &{\frac{F}{4}} &{ } &{ } &{\text { E }} &{\frac{\pi}{U}} &{ } &{ } &{\text { 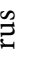 }} &{\frac{7}{U}} &{ } &{ } &{\text { E }} \\
{\hline} &{ } &{0} &{ } &{ } &{ } &{\text { s }} &{ } &{ } &{ } &{ } &{ } &{ } &{ } &{\text { r }} &{ } &{ } &{ } &{\text { 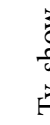 }} &{ } &{ } \\
$\hline
\end{tabular}


provoking to the Chinese respondents (see Figure 5). "Lunch" was rated as kinder and more thought-provoking by the Chinese respondents (see Figure 6). "Sunset" seemed more cheerful, important, kind, and thought-provoking to the Chinese compared to the Russians (see Figure 7).

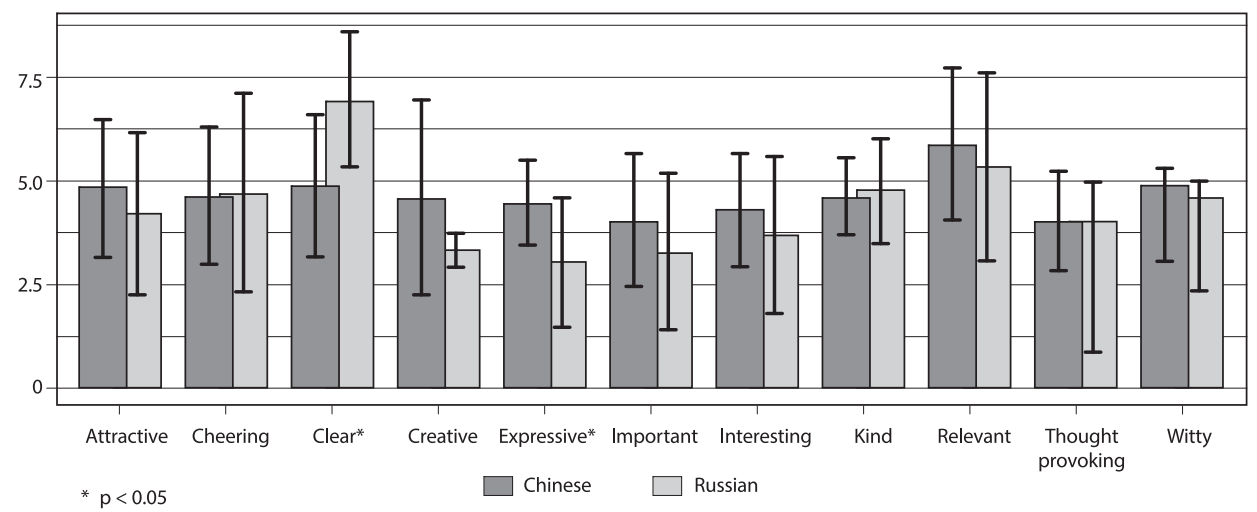

Figure 2. "TV-show" assessment by nationality

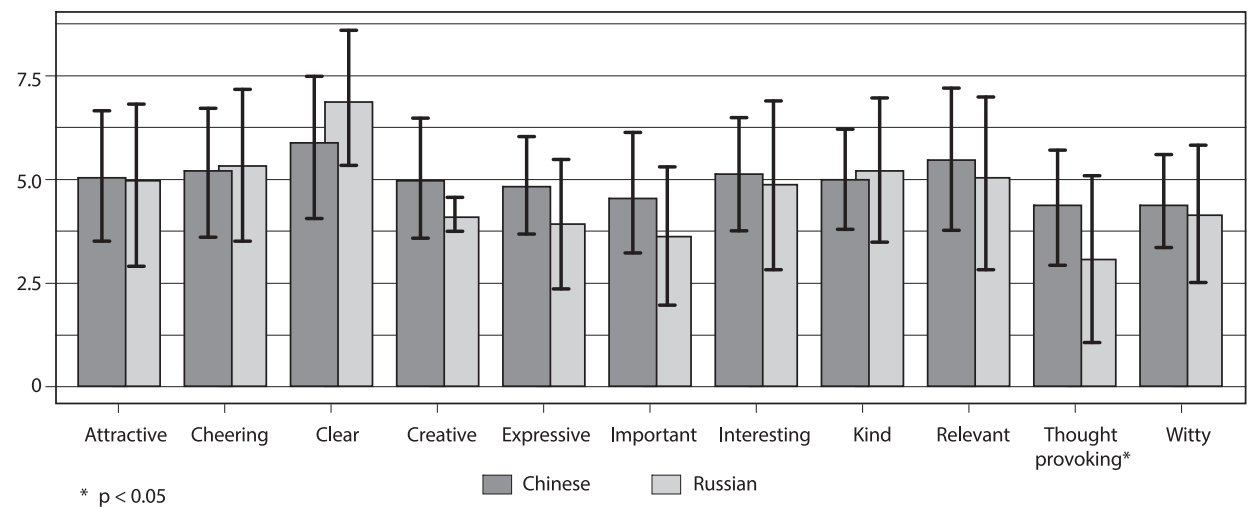

Figure 3. "Cat" assessment by nationality

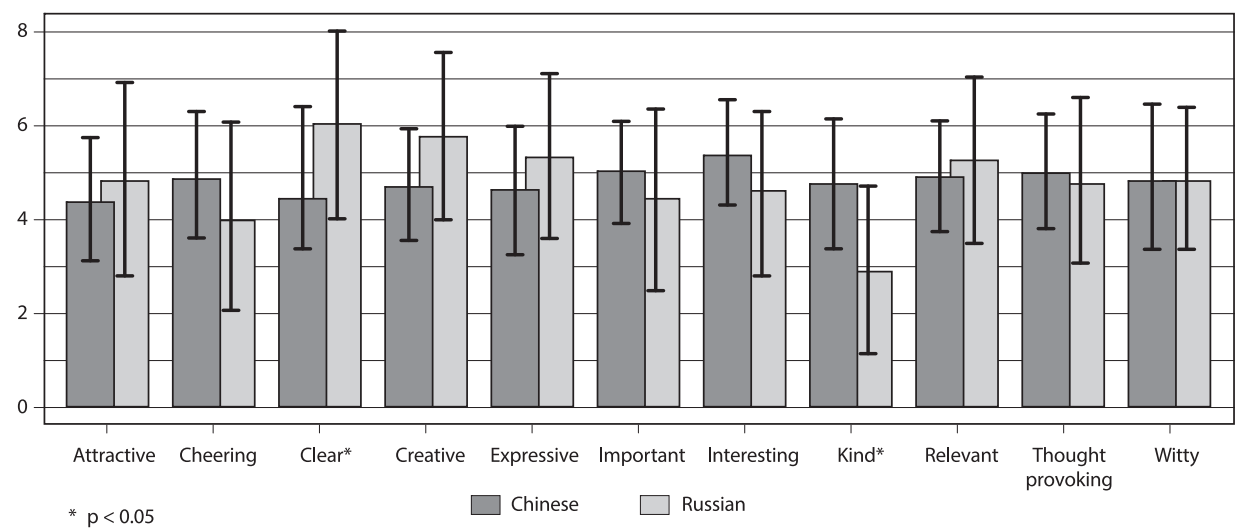

Figure 4. "Green" assessment by nationality 


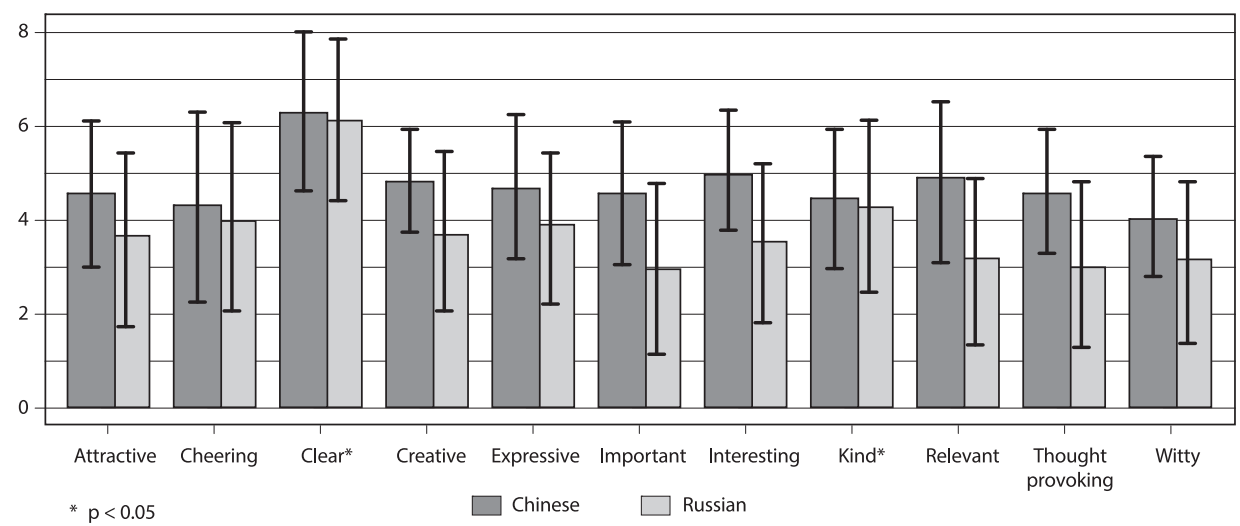

Figure 5. "Girls" assessment by nationality

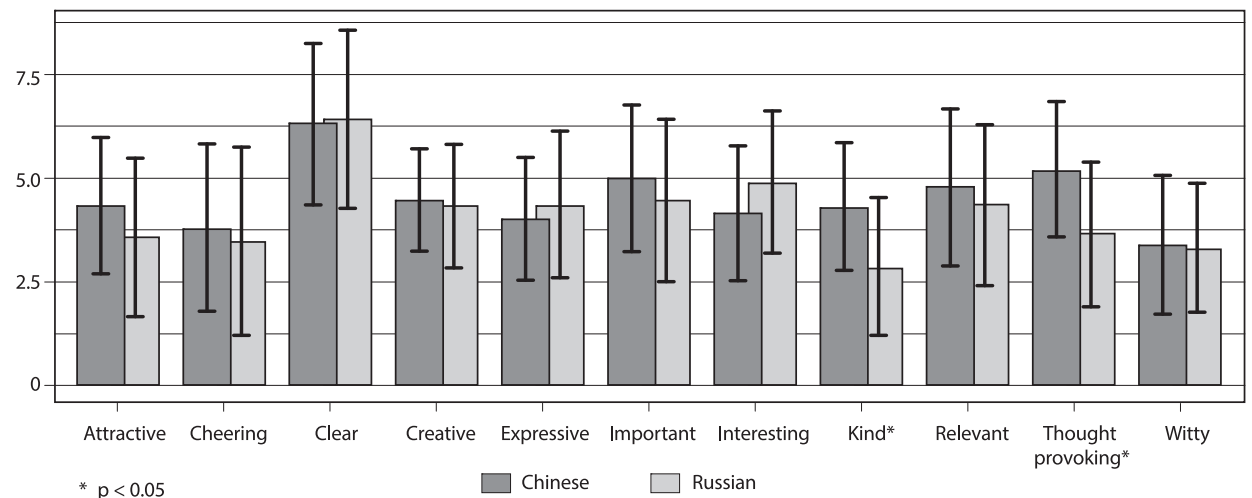

Figure 6. "Lunch" assessment by nationality

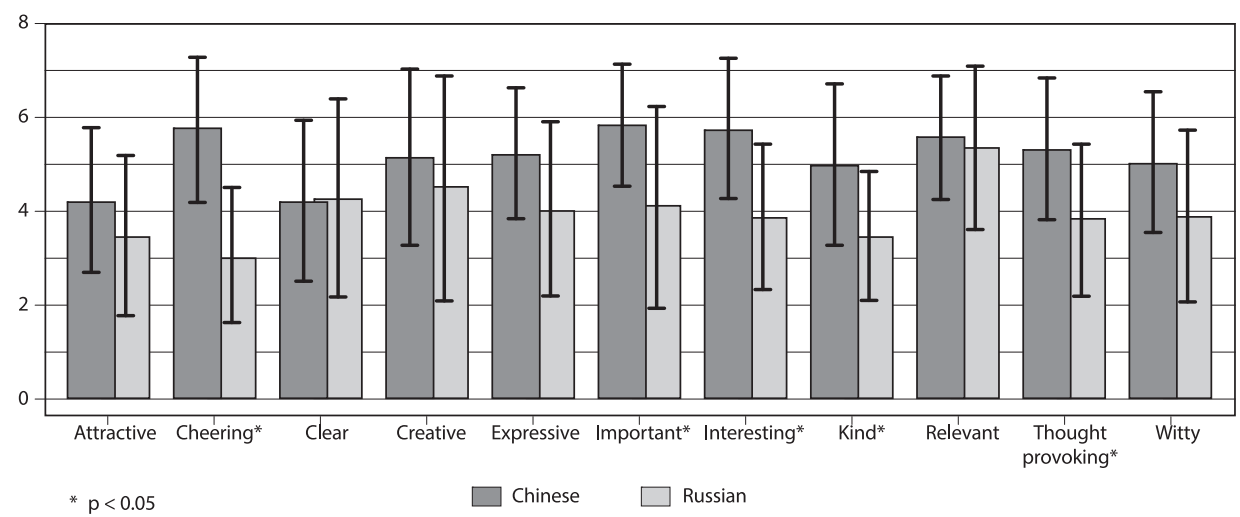

Figure 7. "Sunset" assessment by nationality

\section{Discussion}

Our hypothesis was confirmed through both the respondents' answers to the questionnaire and the test. Indeed, COVID-19 memes in such ethnoculturally different audiences as Russians and Chinese serve a compensatory function for young peo- 
ple, helping them overcome, through their relevant content and creative form, the hardships of the pandemic. A new communication medium, which offers entirely different information opportunities and relations between the audience and the medium, requires researchers to explore and understand these new realities, which affect, among other things, the functioning and audience perception of the content related to healthy living and, in particular, the issue of the COVID-19 pandemic.

Further research may include a t-test for a broader group of respondents, and the study of perception of memes by respondents with different demographic profiles (gender, age, education, etc.), as well as the dispersion analysis of repeatedmeasures ANOVAs to examine differences in emotional responses between different memes. Another important line of further research would be the analysis of memes in the context of different language cultures, and the study of the perception of memes in terms of content comprehensibility, the degree of involvement in the situation, and the level of knowledge of the original culture. In addition, the immediate task of this project was to analyze the visual imagery of memes and its semiotic relationship to the text in more detail.

\section{Conclusion}

As a whole, the Russian and Chinese respondents shared a common view on basic issues related to the functions, content, and form of Internet memes, as well as the key trends on their impact on people during the COVID-19 pandemic. This fact argues in favor of a "post-national" global picture, even despite the differences in the perception of Internet memes on the same topical subject. Some specific conclusions include the following.

Memes that evoked a positive response from the respondents and cheered them up were scored the highest. Such qualities as relevance, kindness, cheerfulness, creativity, meaningfulness, and thought-provoking ability were rated high. Each group of respondents gave a higher score to "our own" memes and a lower score to the other group's memes. However, it should be noted that it is generally typical of the Chinese respondents to have a more positive perception of reality than the Russians, and to be more tolerant of memes representing another culture. The Russian respondents demonstrated a rather sober and skeptical view of the issues and the ways they are depicted in memes. For many memes, the average score given by Russian and Chinese respondents was quite similar, but on average, the Russian scores were 0.3 points lower than the Chinese ones.

We ascertained a tendency toward polarization of opinions and focus on individualization among the Russian respondents, whereas the Chinese respondents strove for orderliness and consensus; this was particularly evident when analyzing the preferred subjects of the memes related to the COVID-19 pandemic. There was a marked difference in the preferred subjects between the two: the Russians were more concerned about self-isolation while the Chinese put greater emphasis on topics related to prevention, virus origin, combating the virus, people's behavior during the pandemic, and the heroic work of doctors. There was a clear gender polarity in the perception of memes among the Russian respondents. At the same time, male Chinese respondents were notably closer in their scores and the perception of memes to both female Chinese and Russian respondents. Animal memes 
got the most positive feedback. It appears that using animals as the image is appealing for both cultures, probably because it is a version or replication of a universal invariant (the animal).

\section{Limitations}

This research had some limitations. There were a limited number of respondents, most of them were female students, and the Russian participants were mostly from Moscow. Another limitation was an insufficient breadth of language cultures represented (the comparative analysis included only the Russian and Chinese language cultures). In addition, the issue of the visual imagery of memes and its semiotic relationship to the text has been poorly studied.

\section{Acknowledgments}

This research did not receive any specific grant from funding agencies in the public, commercial, or not-for-profit sectors.

\section{References}

Assari, S. (2019). High sense of mastery reduces psychological distress for African American women but not African American men. Archives of General Internal Medicine, 3 (1), 5-9. Retrieved from https://www.ncbi.nlm.nih.gov/pmc/articles/PMC6615738/

An, L., Cong, Z., \& Wang, X. (2004). Research of high school students' security and the relatied factors. Chinese Mental Health Journal, 10, 717-719. Retrieved from https://caod.oriprobe.com/ articles/8221746/

Baowei, Zh., \& Xinning, Zh. (2020). On the Responsibility and Mission of News Media in the Spread of COVID-19-Based on the Analysis and Thinking of the Epidemic Situation and Anti-epidemic Reports in China. Journalism Lover, 4, 9-16. https://doi: 10.16017/j.cnki.xwahz.2020.04.003.

Bekhterev, V.M. (1999). Izbrannye trudy po psikhologii lichnosti [Selected Works on the Psychology of Personality]. S.-Petersburg: Aleteya.

Bennetter, K.E., Clench-Aas, J., \& Raanaas, R.K. (2016). Sense of mastery as mediator buffering psychological distress among people with diabetes. Journal of Diabetes and Its Complications, 30 (5), 839-844. https://doi.org/10.1016/j.jdiacomp.2016.03.022

Blackmore, S. (1999). The Meme Machine. Oxford: Oxford University Press.

Blackmore, S. (2010). The Third Replicator. Retrieved from http://opinionator.blogs.ny-times. com/2010/08/22/the-third-replicator.

Brodie, R. (1996). Virus of the Mind: The New Science of the Meme. Seattle: Integral Press.

Castaño, D. (2013). Defining and Characterizing the Concept of Internet Meme. Revista CES Psicología, 6(2), 82-104. https://doi.org/10.1177/2167479515584045

Chaoqun, X., \& Ziran, H. (2007). A Brief Introduction to Language Memetics. Modern Foreign Languages, $1,30-39$.

Davison, P. (2012). The Social Media Reader. New York, NY: NY University Press.

Dawkins, R. (1976). The Selfish Gene. Oxford: Oxford University Press.

Dawkins, R. (1997). Viruses of the Mind. Retrieved from https://www.inf.fu-berlin.de/lehre/pmo/eng/ Daw-kins-MindViruses.pdf

Dennett, D. (1995). Darwin's Dangerous Idea. New York, NY: Simon \& Schuster.

Denissova, G. (2020). Intertekst v sovremennoy sotsiokul'turnoj real'nosti Rossii i Italii [Intertext in the Modern-Day Sociocultural Reality of Russia and Italy]. Moscow: Kanon+.

Dunas, D., \& Vartanov, S. (2020). Emerging digital media culture in Russia: modeling the media consumption of Generation Z. Journal of Multicultural Discourses, 2, 186-203. https://doi.org/10.10 80/17447143.2020.1751648 
Epshteyn, M. (2006). Proektivnyj slovar' russkogo yazyka [Projective Dictionary of the Russian Language]. In Ju.S. Stepanov (Ed.), Semiotika avangarda [Semiotics and Avant-garde] (pp. 1031-1076). Moscow: Kul'tura.

Fang, Zh., \& Haochen, G. (2020). On the Influence of Temporal and Spatial Distance from Epidemic on Public Sentiment: A Computational Analysis Based on Panel Data of Web Text about COVID-19. Journalism and Mass Communication Monthly, 6, 39-49.

Frolova, T.I., \& Striga, E.A. (2020). Gotovnost' rossijskih zhurnalistov k prodvizheniyu cennostej zdorovogo obraza zhizni. [Russian journalists' readiness for healthy lifestyle values promotion]. Vestnik Moskovskogo universiteta. Seriya 10: Zhurnalistika [Moscow University Journalism Bulletin], 3, 29-56. https://doi.org/10.30547/vestnik.journ.3.2020.2955

Gadalla, T.M. (2009). Sense of mastery, social support, and health in elderly Canadians. Journal of Aging Health, 21(4), 581-595. https://doi.org/10.1177/0898264309333318

Green, B.L., \& Rodgers, A. (2001). Determinants of social support among low-income mothers: A longitudinal analysis. American Journal of Community Psychology, 29(3), 419-441. https://doi. org/10.1023/A:1010371830131

Holbrook, T.L., Hoyt, D.B., Coimbra, R., Potenza, B., Sise, M., \& Anderson, J.P. (2005). High rates of acute stress disorder impact quality-of-life outcomes in injured adolescents: mechanism and gender predict acute stress disorder risk. Journal of Traumatic Stress, 59, 1126-1130. https://doi. org/10.1097/01.ta.0000196433.61423.f2

Jieling, Ch., Xinchun, W., Panpan, Z., Xiao, Z., \& Guoyu, X. (2014). The relationship between PTSD and PTG: evidence from longitudinal study of teachers survived in Wenchuan earthquake. Psychological Development \& Education, 30, 75-81.

Kang, L., Li, Y., Hu, S., Chen, M., Yang, C., Yang, B., \& Liu, Z. (2020). The mental health of medical workers in Wuhan, China dealing with the 2019 novel coronavirus. The Lancet Psychiatry, 7(3), e14. https://doi.org/10.1016/S2215-0366(20)30047-X

Kartashova, E., \& Akhmedzianova, A. (2019). Internet-mem kak osnovnoy vid kreolizovannogo teksta v samoprezentatsii «cheloveka govoryashchego» [Internet-meme as the basic type of creolized texts in self-presentation of «creative human»]. Vestnik Mariiskogo universiteta [Mari State University Bulletin], 3(35), 426-430. https://doi.org/10.30914/2072-6783-2019-13-3-426-430

Keeton, C.P., Perry-Jenkins, M., \& Sayer, A.G. (2008). Sense of control predicts depressive and anxious symptoms across the transition to parenthood. Journal of Family Psychology, 22(2), 212-221. https://doi.org/10.1037/0893-3200.22.2.212

Ksenofontova, I. (2009). Spetsifika kommunikatsii v usloviyakh anonimnosti: memetika, imidzhbordy, trolling [The Specifics of Communication under Conditions of Anonymity: memetics, image boards, trolling]. In A.S. Kargin (Ed.), Internet i fol'klor [Internet and folklore] (pp. 280-292). Moscow: Tsentr russkogo fol'klora.

Krongauz, M., Litvin, E., \& Merzljakova, V. (2017). Slovar' yazyka interneta.ru [Internet.ru language dictionary]. Moscow: AST.

Leontiev, A. (1997). Osnovy psikholingvistiki [Fundamentals of Psycholinguistics]. Moscow: Smysl.

Lynch, A. (1996). Thought Contagion: How Belief Spreads Through Society. N.Y.: Basic Books.

Martire, L.M., Stephens, M.A.P., \& Townsend, A.L. (1998). Emotional support and well-being of midlife women: Role-specific mastery as a mediational mechanism. Psychology and Aging, 13(3), 396-404. https://doi.org/10.1037//0882-7974.13.3.396

Meiying, T. (2010). New Exploration of Network Language. Zhengzhou: Henan People's Publishing House.

Pestova, M., \& Safonov, E. (2020). Pandemiya novogo desyatiletiya: osveshchenie temy koronavirusa v SMI. Mediasreda, 1, 166-172.

Plotkin, H. (1993). Hunting memes. Behavioral and Brain Sciences, 16(4), 768-769. https://doi. org/10.1017/S0140525X00032891

Rushkoff, D. (1994). Media Virus: Hidden Agendas in Popular Culture. N.Y.: Ballantine Books.

Shi-xu (2009). Reconstructing Eastern paradigms of discourse studies. Journal of Multicultural Discourses, 4(1), 29-48. https://doi.org/10.1080/17447140802651637

Shi-xu (2016). Cultural Discourse Studies through the Journal of Multicultural Discourses: 10 years on. Journal of Multicultural Discourses, 11(1), 1-8. https://doi.org/10.1080/17447143.2016.1150936 
Shomova, S. (2018). Memy kak oni est' [Meme as they are]. Moscow: Aspekt Press.

Sorokin, Ju., \& Tarasov, E. (1990). Kreolizovannye teksty i ikh kommunikativnaya funkciya [Created Texts and their Communicative Function]. Moscow: Azbukovnik.

Sperber, D. (1996). Explaining Culture: A Naturalistic Approach. Oxford: Blackwell.

Sture, H. (1979). A Simple Sequentially Rejective Multiple Test Procedure. Scandinavian Journal of Statistics, 6(2), 65-70. Retrieved from http://www.jstor.org/stable/4615733.

Tao, J.H. (2006). Influence of acute psychological stress and exercise stress on the changes of immune function. Chinese Journal of Clinical Rehabilitation, 10, 126-128.

Vartanova, E. (2019). Russian media change as a cultural process. European Journal of Communication, 34(2), 205-210. https://doi.org/10.1177/0267323119838088.

Vartanova, E., Cherevko, T., Tolokonnikova, A., \& Dunas, D. (2019). Changing patterns of digital news consumption among Russian journalism students. World of Media. Journal of Russian Media and Journalism Studies, 1, 7-31. https://doi.org/10.30547/worldofmedia.1.2019.1

Vartanova, E., \& Gladkova, A. (2020). Old and new discourses in Emerging States: communication challenges of the digital age. Journal of Multicultural Discourses, 15(2), 119-125. https://doi.org/ $10.1080 / 17447143.2020 .1780244$

Wiggins, B.E., \& Bowers, G.B. (2015). Memes as Genre: A Structural Analysis of the Memescape. New Media \& Society, 17(11), 1886-1906. https://doi.org/10.1177/1461444814535194

Xiao, Zh., \& Benxian, Y. (2020). Social support and acute stress symptoms (ASSs) during the COVID-19 outbreak: deciphering the roles of psychological needs and sense of control. European Journal of Psychotraumatology, 11(1), 1-8. https://doi.org/10.1080/20008198.2020.1779494

Yunhui, Zh. (2010). Research on Internet Language Grammar and Pragmatics. Shanghai: Xuelin Publishing House.

Zizevskaia, E., \& Shchukina, M. (2018). Gender schemas in perception of gender-neutral images. Psychology in Russia, 11(1), 151-163. https://doi.org/10.11621/pir.2018.0112

Zinchenko, Yu., Shaigerova, L., \& Soldatova, G. (2016). Razrabotka i aprobatsiya kompleksnoj psikhodiagnosticheskoj metodiki izucheniya etnokulturnoj identichnosti: metodologicheskie printsipy $i$ tekhnicheskie resheniya [Development and testing of a com-plex psychodiagnostic methods for the study of ethnic and cultural identity: methodologi-cal principles and technical decisions]. In Yu.P. Zinchenko \& L.A. Shaigerova (Eds.), Etnokul'turnaya identichnost kak factor sotsialnoj stabil'nosti v sovremennoj Rossii, tom 1 [Ethno-cultural identity as a factor of social stability in modern Russia, Vol. 1], (pp. 150-193). Moscow: Moscow University Press.

Original manuscript received July 08, 2020

Revised manuscript accepted November 19, 2020

First published online December 30, 2020

To cite this article: Smirnova, O.V., Denissova, G.V., Svitich, L.G., Lin, C., Steblovskaia, S.B., Antipova, A.S. (2020). Psychological and Ethnocultural Sensitivities in the Perception of COVID-19 Memes by Young People in Russia and China. Psychology in Russia: State of the Art, 13(4), 148-167. DOI: 10.11621/pir.2020.0410 